\title{
Effects of Curcumin on Sperm Motility, Viability, Mitochondrial Activity and Plasma Membrane Integrity in Boar Semen
}

\author{
A-Sung Lee ${ }^{1}$, Sang-Hee Lee ${ }^{2}$, Seunghyung Lee ${ }^{1}$ and Boo-Keun Yang ${ }^{1, \dagger}$ \\ ${ }^{1}$ College of Animal Life Sciences, ${ }^{2}$ Institute of Animal Resources, Kangwon National University, \\ Chuncheon 24341, Korea
}

\begin{abstract}
Curcumin is known as a natural antioxidant, decreasing oxidative stress in animal cells. Generally, oxidative stress induces reactive oxygen species in sperm and leads to decreased sperm characteristics in pigs. Therefore, this study investigated the influence of curcumin on sperm motility, viability, mitochondrial activity and plasma membrane integrity in pigs. Curcumin $(0,5$ and $10 \mu \mathrm{M})$ was treated in boar semen, which were incubated for 9 hours in $37^{\circ} \mathrm{C}$. Then, motility, viability, mitochondrial activity, plasma membrane integrity of sperm was analyzed every 3 hours. In the results, sperm motility was significantly increased by $5 \mu \mathrm{M}$ curcumin after 3 and 9 hours after incubation, and viability was significantly higher in $5 \mu \mathrm{M}$ curcumin treatment at 3 hours $(P<0.05)$. Similarly, sperm mitochondrial activity and plasma membrane integrity were significantly increased by $5 \mu \mathrm{M}$ curcumin at 3,6 and 9 hours after incubation $(P<0.05)$. There results suggest that curcumin improve sperm characteristics such as motility, viability, mitochondrial activity, and plasma membrane integrity, and may exert a positive effect on sperm fertility in pigs.
\end{abstract}

Key Words: Curcumin, Motility, Viability, Plasma membrane integrity, Sperm

높은 수준의 활성산소는 DNA 손상, 지질 과산화 및 단백질 변성을 포함한 세포 내 많은 악영향을 끼치며 산 화 스트레스를 유발시켜 남성의 불임을 유발하는 주요 원 인으로 알려져 있다(Ko et al., 2014). 이러한 활성산소를 제거해주는 항산화제는 포유동물에 있어 수컷의 생식 기 관과 세포를 보호하는 역할을 하기 때문에 번식 능력을 향상시키기 위한 항산화제의 연구는 활발하게 진행되고 있다(Ciftci et al., 2011; Głombik et al., 2014).

Curcumin (1,7-bis(4-hydroxy-3-methoxy phenyl)-1,6-heptadiene-3,5-dione)은 Curry나 Turmeric (Curcuma longa)에 포함 되는 황색 안료 성분으로, 생물학적 특성에 대한 연구가 다양한 방면에서 이루어지고 있다(Tayyem et al., 2006; He et al., 2015; Vallianou et al., 2015). 특히 curcumin은 포유동물에 있어 항산화, 항염증, 항당뇨 및 항암 작용을 하는 중요
한 물질로 알려져 있다(Aggarwal et al., 2007; El-Bahr 2013; Ghosh et al., 2015). 실제로 curcumin은 cadmium 및 imidacloprid에 노출된 쥐에서 정자를 보호(Lonare et al., 2015; Oguzturk, 2012)하며, 2,3,7,8-Tetracholorodibenzo-p-dioxin (TCDD)에 의한 산화적 손상을 감소(Ciftci et al., 2011)시킨 다고 알려져 있다. 또한 curcumin은 di-2-ethylhexyl phthalate에 의한 세포 사멸을 완화시켜 정자 운동성에 긍정적 인 영향(Głombik et al., 2014)을 줄 뿐만 아니라 수컷의 생식세포를 보호하는 역할(Gobbo et al., 2015)한다고 알려 져 있기 때문에 curcumin이 산화 스트레스로부터 유발되 는 번식 기능 및 불임 등에 긍정적인 효과를 미칠 것으로 보여진다. 하지만 돼지 정자에서 curcumin을 사용하는데 있어 적합한 농도와 적절한 노출시간에 대한 연구는 보고 되지 않았기 때문에 본 연구에서는 돼지 정자를 이용하여

* Received: September 5, 2017 / Revised: October 13, 2017 / Accepted: October 13, 2017

${ }^{\dagger}$ Corresponding author: Boo-Keun Yang. College of Animal Life Science, Kangwon National University, Chuncheon 24341, Korea.

Tel: +82-33-250-8623, Fax: +82-33-259-5572, e-mail: bkyang@kangwon.ac.kr

(C) The Korean Society for Biomedical Laboratory Sciences. All rights reserved.

(C) This is an Open Access article distributed under the terms of the Creative Commons Attribution Non-Commercial License (http://creativecommons.org/licenses/by-nc/3.0/) which permits unrestricted non-commercial use, distribution, and reproduction in any medium, provided the original work is properly cited. 
천연 항산화제인 curcumin의 효과를 검증하고 최적의 농 도 및 노출시간에 대하여 알아보고자 연구를 실시하였다. 모든 동물실험은 강원대학교 동물실험윤리위원회의 승 인(KIACUC-09-0139)을 얻어 수행하였고, 본 실험에서 사 용된 curcumin (C1386)은 Sigma-Aldrich Chemical Company (St. Louis, MO, USA)로부터 구입하여 사용하였다. 시료의 수집을 위하여 Duroc, Yorkshire 및 Landrace가 교잡된 수 컷 돼지에서 음경수압법을 이용해 정액을 채취하였으며, 돼지 정액희석액인 modena (Lee et al., 2017)로 혼합하여 희 석 정액의 농도를 $1.0 \times 10^{7}$ 개/mL가 되도록 한 후 $17^{\circ} \mathrm{C}$ 의 상태로 2시간 이내 실험실로 운반하여 실험에 사용하였 다. 이 후 $37^{\circ} \mathrm{C}, 5 \% \mathrm{CO}_{2}$ 조건에서 총 9시간 동안 정자를 배양하며 3 시간 간격으로 정자의 운동성, 생존율, 미토콘 드리아 활성 및 원형질막의 온전성 분석을 실시하였다. 정 자의 운동성을 관찰하기 위하여 $37^{\circ} \mathrm{C}$ 의 가온판에서 10 분 이상 가온시킨 slide glass에 정액 시료 $20 \mu \mathrm{L}$ 를 떨어뜨린 후 cover glass를 덮은 뒤, 위상차 현미경(Nicon, Japan)으로 200 배율 하에 운동성을 검사하였으며, 정자의 미부가 움 직이는 것을 운동이 있는 정자로 판단하였다.

정자의 생존율 검사는 Hoechest $33342(\mathrm{HO})$ / propidium iodide (PI) 염색 방법을 사용하였다. $100 \mu \mathrm{L}$ 정액 시료에 $0.5 \mathrm{mg} / \mathrm{mL}$ PI 용액을 $10 \mu \mathrm{L}$ 첨가 후 $37^{\circ} \mathrm{C}$ 에서 5 분간 정치 시킨 후, $0.5 \mathrm{mg} / \mathrm{mL} \mathrm{HO}$ 용액을 $10 \mu \mathrm{L}$ 를 첨가 후 $37^{\circ} \mathrm{C}$ 에서 10 분간 정치시켰다. 이 후 염색된 정액 시료 $20 \mu \mathrm{L}$ 를 slide glass에 분주 후 epifluorescence microscope (Ziess, Germany) 를 이용해 400 배율 $460 / 500 \mathrm{~nm}$ 파장 하에서 관찰하였다. 살아있는 정자는 파란색, 죽은 정자는 붉은색으로 판단하 였다.

미토콘드리아 기능 검사를 위하여 Rhodamin123 (R123) / PI 염색 방법을 이용(Lee and Park, 2015)하였으며, $1 \mathrm{~mL}$ 의 정자 시료에 $3 \mu \mathrm{L}$ 의 $0.5 \mathrm{mg} / \mathrm{mL} \mathrm{R} 123$ 용액을 첨가한 뒤 $37^{\circ} \mathrm{C}$ 에서 15 분간 정치시킨 후 $0.5 \mathrm{mg} / \mathrm{mL}$ PI 용액을 $10 \mu \mathrm{L}$ 넣고 10 분간 추가적으로 배양하였다. 미토콘드리아 기능 은 epifluorescence microscope (Ziess)로 400 배율 하에 R123 은 490/515 nm 파장에서 PI는 545/590 nm에서 관찰하였다. 중편부가 녹색 형광을 띄는 정자가 미토콘드리아의 정상 기능을 하는 것으로 판단하였다.

정자의 원형질막 기능 검사는 hypoosmotic swelling test (HOST)로 검사하였고, 정액 $50 \mu \mathrm{L}$ 와 $1 \mathrm{~mL}$ 의 hypo-osmotic solution (624.9 mM Na-citrate 및 $74.9 \mathrm{mM}$ fructose)을 혼합 후 $37^{\circ} \mathrm{C}$ 에서 30 분간 배양하였다. 이 후 slide glass에 시료 $20 \mu \mathrm{L}$ 를 떨어뜨린 후 cover glass를 덮은 뒤, 위상차 현미

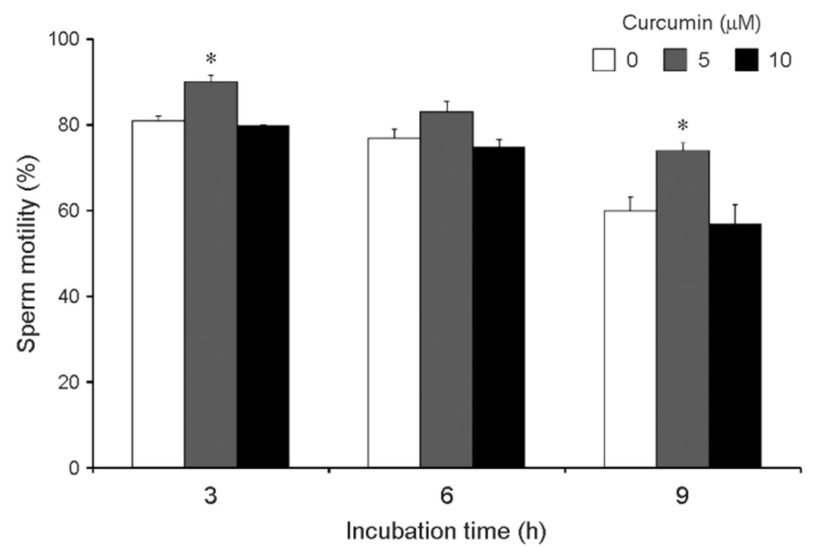

Fig. 1. Effect of curcumin on boar sperm motility during liquid storage. Liquid semen was incubated in semen extender containing with 0,5 and $10 \mu \mathrm{M}$ curcumin for 9 hours, Bars represent means \pm standard error of the mean (SEM). *Within the histogram, similarly shaded bars with different letters are significantly different $(P<0.05)$.

경(Nicon)으로 200 배율 하에서 검사하였으며, 정자의 꼬 리가 감겨 있거나, 나선형으로 감겨져 있으면 원형질막의 기능이 정상인 것으로 판단했다.

또한 정자의 생존율, 미토콘드리아 기능 및 원형질막 검 사를 위하여 시료마다 최소 500 개 이상의 정자를 관찰하 여 백분율로 환산하였으며, 본 실험에서 얻어진 모든 결 과는 Statistical Analysis System software version 9.2 (SAS Institute Inc. USA)를 이용하여 분산 분석을 실시하였으며, Duncan's multiple range test을 실시하여 통계처리를 실시하 였다. 결과의 유의성은 $P<0.05$ 수준에서 유의성을 검정하 였다.

그 결과 Fig. 1에서 나타난 바와 같이 정자의 활력은 3 및 9시간 동안 배양하였을 때 $5 \mu \mathrm{M}$ curcumin 첨가구에서 유의적 $(P<0.05)$ 으로 증가한 것을 확인할 수 있었으며, 5 $\mu \mathrm{M}$ curcumin이 배양시간 동안 정자의 생존율을 유의적 $(P<0.05)$ 으로 증가시키는 걸 확인하였다(Fig. 2). 이뿐만 아니라 미토콘드리아 활성의 경우 배양시간과 관계 없이 $5 \mu \mathrm{M}$ curcumin 처리구에서 유의적 $(P<0.05)$ 으로 증가된 것 을 확인하였다(Fig. 3). 일반적으로 curcumin은 미토콘드리 아의 활성을 향상시킬 뿐만 아니라 비소에 의한 미토콘드 리아 독성을 감소시킨다고 알려져 있기 때문에 curcumin 에 의한 돼지 정자의 미토콘드리아 활성 증가는 이전의 연구 결과와 일치된다고 사료된다(Muthumani et al., 2015; Zhang et al., 2015). 정자의 운동성에 이용되는 ATP는 미토 콘드리아로부터 생성되기 때문에 미토콘드리아 활성은 


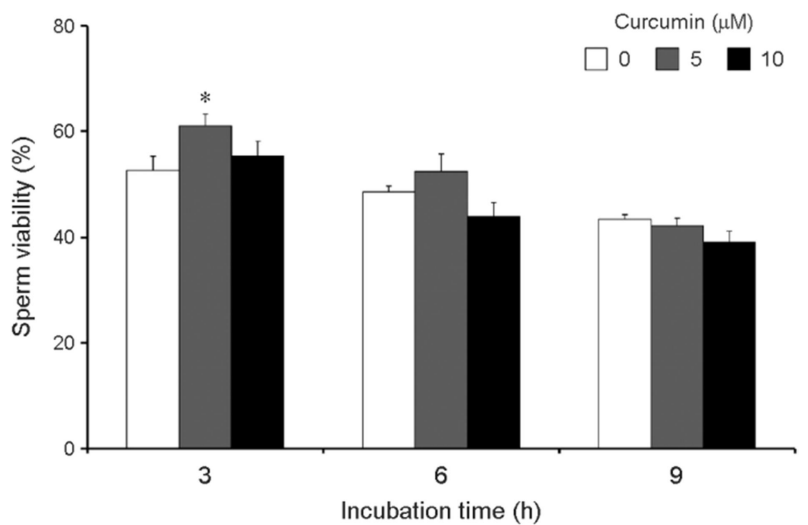

Fig. 2. Effect of curcumin on boar sperm viability during liquid storage. Liquid semen was incubated in semen extender containing with 0,5 and $10 \mu \mathrm{M}$ curcumin for 9 hours, and sperm viability was analyzed using Hoechst 33342 and propidium double staining assay. Bars represent means \pm standard error of the mean (SEM). *Within the histogram, similarly shaded bars with different letters are significantly different $(P<0.05)$.

운동성과 밀접한 연관성을 가지고 있다(Ruiz-Pesini et al., 1998; Sariozkan et al., 2009). 또한 미토콘드리아는 세포 사 멸을 조절하는 $\mathrm{Bcl}-2$ 단백질이 위치한 주요 소기관으로 알려져 있다(Chen et al., 2015). 따라서 curcumin은 미토콘 드리아 활성을 향상시켜 정자에 필요한 운동성을 증진시 켰을 뿐만 아니라 세포 사멸을 억제하여 생존율을 향상시 켰다고 생각된다.

정자 세포막 온전성은 Fig. 4에서 나타난 바와 같이 배 양시간과 관계 없이 $5 \mu \mathrm{M}$ curcumin에 의해 유의적으로 증 가되었다 $(P<0.05)$. 세포막은 세포 내부와 외부를 구분지어 주는 경계인 동시에 세포 내외의 물질 수송이나 신호 전 달을 담당하고 있는 중요한 기관이다(Shafiei et al., 2015). 포유류에서 정자의 세포막 지질 성분은 체세포와는 다르 게 인지질을 포함한 포화 및 불포화 지방산이 매우 높은 함량을 보이며, 따라서 과도한 활성산소 노출에 특히 민감 하다(Kemal Duru et al., 2000; Sanocka et al., 2004). 또한 첨 체 반응 및 정자와 난자의 수정에 있어 중요한 역할을 함 으로 수정 능력에 대한 평가로 작용할 수 있다(Shafiei et al., 2015). 본 실험 결과에서 정자의 원형질막 안정성이 curcumin에 의해 증가됨을 확인하였고, curcumin이 다양한 충격으로부터 발생할 수 있는 원형질막의 손상을 개선시 킬 수 있는 것을 확인하였다.

이러한 결과를 종합하여 보았을 때 $5 \mu \mathrm{M}$ curcumin은 돼 지 정자의 운동성, 미토콘드리아 활동성 및 원형질막 온

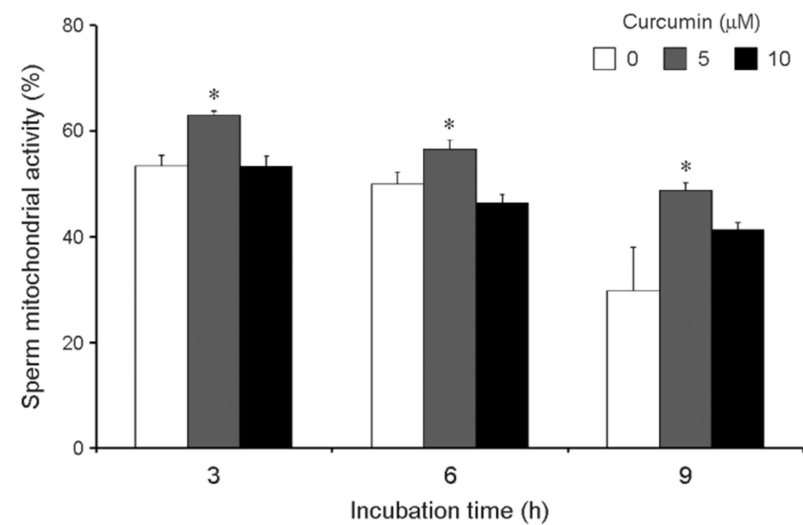

Fig. 3. Influence of curcumin on boar sperm mitochondrial activity during liquid storage. Liquid semen was incubated in semen extender containing with 0,5 and $10 \mu \mathrm{M}$ curcumin for 9 hours, and sperm mitochondrial was analyzed using rhodamine 123 and propidium double staining assay. Bars represent means \pm standard error of the mean (SEM). *Within the histogram, similarly shaded bars with different letters are significantly different $(P<0.05)$.

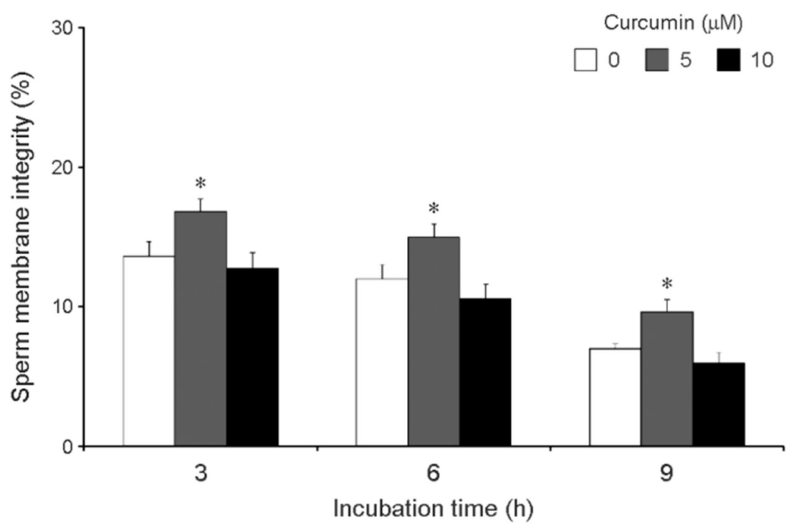

Fig. 4. Effect of curcumin on boar sperm plasma membrane integrity during liquid storage. Liquid semen was incubated in semen extender containing with 0,5 and $10 \mu \mathrm{M}$ curcumin for 9 hours, and sperm plasma membrane integrity was analyzed using hypoosmotic swelling test. Bars represent means \pm standard error of the mean (SEM). *Within the histogram, similarly shaded bars with different letters are significantly different $(P<0.05)$.

전성에 긍정적인 영향을 미쳤으나 $10 \mu \mathrm{M}$ curcumin 처리구 의 경우 정자의 성상이 대조구와 차이가 없거나 오히려 낮아지는 것으로 보았을 때 $10 \mu \mathrm{M}$ curcumin은 돼지 정자 에 유해한 영향을 미친다고 판단된다. 이러한 결과는 적 절한 농도의 항산화제는 정자에 이로운 영향을 주지만, 과도한 농도의 항산화제는 정자의 기능을 손상시킨다는 
연구 결과와 일치한다고 사료된다(Kumar et al., 2015). 실제 로 고농도의 curcumin은 정자가 암컷 생식기인 질에서 자 궁경부를 통해 자궁에 들어가기 전에 정자를 죽여 살균 작용을 하는 살정제(Naz et al., 2014)에 사용되기 때문에, $10 \mu \mathrm{M}$ 과 같은 고농도의 curcumin의 돼지 정자에 있어 악 영향을 미쳤을 것이라 생각된다. 실제로 포유동물 생리에 있어 $10 \mu \mathrm{M}$ 이상의 curcumin에 대한 연구 결과(Naz et al., 2014; Rithaporn et al., 2003)를 바탕으로 비추어 보았을 때, 본 실험에서는 돼지 정액에서 curcumin의 항산화제로 작 용할 수 있는 최적의 농도는 $10 \mu \mathrm{M}$ 이하라고 판단하였고, 실제로 $10 \mu \mathrm{M}$ curcumin에 비하여 $5 \mu \mathrm{M}$ curcumin이 돼지 정자의 운동성, 생존성, 미토콘드리아 및 원형질막 온전성 에 이로운 영향을 주는 것으로 나타났다.

따라서 돼지 정액에 있어 $5 \mu \mathrm{M}$ curcumin은 9시간 동안 생식세포인 정자의 기능을 향상시킬 수 있다고 판단된다. 이는 curcumin이 다양한 산화 스트레스로부터 발생할 수 있는 생식세포 손상을 보호하여 포유동물의 번식 능력을 향상시킬 수 있는 항산화제 제제로 이용될 수 있음을 나 타내고 있다.

\section{ACKNOWLEDGEMENTS}

This study was supported by 2016 Research Grant from Kangwon National University (No. 520160128).

\section{CONFLICT OF INTEREST}

The authors have no conflicts of interest to disclose.

\section{REFERENCES}

Aggarwal BB, Sundaram C, Malani N, Ichikawa H. Curcumin: the Indian solid gold. Advances in Experimental Medicine and Biology. 2007. 595: 1-75.

Chen Q, Xu H, Xu, A, Ross T, Bowler E, Hu Y, Lesnefsky EJ. Inhibition of Bcl-2 sensitizes mitochondrial permeability transition pore (MPTP) opening in ischemia-damaged mitochondria. PLOS One. 2015. https://doi.org/10.1371/journal.pone.0118834

Ciftci O, Ozdemir I, Tanyildizi S, Yildiz S, Oguzturk H. Antioxidative effects of curcumin, $\beta$-myrcene and 1,8-cineole against 2,3,7,8-tetrachlorodibenzo-p-dioxin-induced oxidative stress in rats liver. Toxicology and Industrial Health. 2011. 27: 447-453.

El-Bahr SM. Curcumin regulates gene expression of insulin like growth factor, B-cell CLL/lymphoma 2 and antioxidant enzymes in streptozotocin induced diabetic rats. BMC Complementary and Alternative Medicine. 2013. 13: 368-379.

Ghosh S, Banerjee S, Sil PC. The beneficial role of curcumin on inflammation, diabetes and neurodegenerative disease: A recent update. Food and Chemical Toxicology. 2015. 83: 111 $-124$

Głombik K, Basta-Kaim A, Sikora-Polaczek M, Kubera M, Starowicz G, Styrna J. Curcumin influences semen quality parameters and reverses the di (2-ethylhexyl) phthalate (DEHP) -induced testicular damage in mice. Pharmacological Reports. 2014. 66: 782-787.

Gobbo MG, Costa CF, Silva DG, de Almeida EA, Góes RM. Effect of melatonin intake on oxidative stress biomarkers in male reproductive organs of rats under experimental diabetes. Oxidative Medicine and Cellular Longevity. 2015. doi: 10.1155/ 2015/614579.

He Y, Yue Y, Zheng X, Zhang K, Chen S, Du Z. Curcumin, inflammation, and chronic diseases: how are they linked? Molecules. 2015. 20: 9183-9213.

Kemal Duru N, Morshedi M, Oehninger S. Effects of hydrogen peroxide on DNA and plasma membrane integrity of human spermatozoa. Fertility and Sterility. 2000. 74: 1200-1207.

Ko EY, Sabanegh ES, Agarwal A. Male infertility testing: reactive oxygen species and antioxidant capacity. Fertility and Sterility. 2014. 102: 1518-1527.

Lee A, Lee SH, Lee S, Yang BK. Effects of streptozotocin, bisphenol A and diethylstilbestrol on production of reactive oxygen species and lipid peroxidation in the boar sperm. Biomedical Science Letter. 2017. 6: 128-132.

Lee SH, Park CK. Effect of magnetized extender on sperm membrane integrity and development of oocytes in vitro fertilized with liquid storage boar semen. Animal Reproduction Science. 2015. 154: 86-94.

Lonare M, Kumar M, Raut S, More A, Doltade S, Badgujar P, Telang A. Evaluation of ameliorative effect of curcumin on imidacloprid-induced male reproductive toxicity in Wistar rats. Environmental Toxicology. 2015. doi: 10.1002.

Naz RK, Lough M. Curcumin as a potential non-steroidal contraceptive with spermicidal and microbicidal properties. European Journal of Obstetrics \& Gynecology and Reproductive Biology. 2014. 176: $142-148$

Oguzturk H, Ciftci O, Aydin M, Timurkaan N, Beytur A, Yilmaz F. Ameliorative effects of curcumin against acute cadmium toxicity on male reproductive system in rats. Andrologia. 2012 44: 243-249. 
Ruiz-Pesini E, Diez C, Lapeña AC, Pérez-Martos A, Montoya J, Alvarez E, Arenas J, López-Pérez MJ. Correlation of sperm motility with mitochondrial enzymatic activities. Clinical Chemistry. 1998. 44: 1616-1620.

Sanocka D, Kurpisz M. Reactive oxygen species and sperm cells. Reproductive Biology and Endocrinology. 2004. 2: 12.

Sariozkan S, Bucak MN, Tuncer PB, Ulutas PA, Bilgen A. The influence of cysteine and taurine on microscopic-oxidative stress parameters and fertilizing ability of bull semen following cryopreservation. Cryobiology. 2009. 58: 134-138.

Shafiei M, Forouzanfar M, Hosseini SM, Esfahani MH. The effect of superoxide dismutase mimetic and catalase on the quality of postthawed goat semen. Theriogenology. 2015. 83: 1321 $-1327$.
Tayyem RF, Heath DD, Al-Delaimy WK, Rock CL. Curcumin content of turmeric and curry powders. Nutrition and Cancer. 2006. 55: 126-131.

Vallianou NG, Evangelopoulos A, Schizas N, Kazazis C. Potential anticancer properties and mechanisms of action of curcumin Anticancer Research. 2015. 35: 645-651.

https://doi.org/10.15616/BSL.2017.23.4.406

Cite this article as: AS Lee, SH Lee, S Lee, BK Yang. Effects of Curcumin on Sperm Motility, Viability, Mitochondrial Activity and Plasma Membrane Integrity in Boar Semen. Biomedical Science Letters. 2017. 23: 406410. 